\title{
Statistik demografi kumbang predator Stethorus punctillum Weise (Coleoptera: Coccinellidae) pada Tetranychus kanzawai Kishida (Acari: Tetranychidae)
}

\author{
Demographic statistics of predatory beetle Stethorus punctillum Weise \\ (Coleoptera: Coccinellidae) on Tetranychus kanzawai Kishida \\ (Acari: Tetranychidae)
}

\author{
Nirma Septia Ramlan Anjas*, Sugeng Santoso, Ali Nurmansyah \\ Departemen Proteksi Tanaman, Fakultas Pertanian, IPB University \\ Jalan Kamper, Kampus IPB Dramaga, Bogor 16680
}

(diterima Desember 2019, disetujui Januari 2021)

\begin{abstract}
ABSTRAK
Tetranychus kanzawai Kishida adalah spesies tungau yang dapat menyebabkan kehilangan hasil pada tanaman pertanian sekitar $60-90 \%$. Salah satu cara untuk mengendalikan tungau hama yang ramah lingkungan adalah dengan menggunakan kumbang predator Stethorus punctillum Weise. Penelitian ini bertujuan untuk menentukan statistik demografi, preferensi, dan tanggap fungsional $S$. punctillum pada T. kanzawai. Pengujian neraca hayati S. punctillum menggunakan 100 telur, dengan mengamati jumlah individu yang masih hidup sampai betina dewasa menghasilkan keturunan. Preferensi S. punctillum terhadap 50 telur dan 50 individu masing-masing nimfa dan imago $T$. kanzawai, dengan mengamati jumlah T. kanzawai yang dimangsa oleh larva instar I, II, III, IV dan imago S. punctillum. Tanggap fungsional dilakukan dengan memberi mangsa S. punctillum sebanyak 30, 40, 50, 60, 70, 80 telur T. kanzawai, pengamatan dilakukan pada jumlah telur yang tersisa. Hasil penelitian menunjukkan bahwa telur $S$. punctillum berlangsung selama 7,01 $\pm 0,72$ hari, larva instar I 4,84 $\pm 0,51$ hari, instar II 3,16 $\pm 0,52$ hari, instar III 3,00 $\pm 0,27$ hari, dan instar IV 2,48 $\pm 0,50$ hari. Kemampuan betina menghasilkan telur sebanyak $64,47 \pm 2,37$ butir. Laju reproduksi kotor (GRR) $S$. punctillum 64,29 individu/generasi, tingkat reproduksi bersih (Ro) 17,18 individu/betina/generasi, laju pertambahan intrinsik (r) 0,27 individu/betina/hari, rata-rata masa generasi (T) adalah 62,41 hari, dan waktu ganda (DT) adalah 2,51 hari. Data menunjukkan bahwa S. punctillum memiliki preferensi stadia telur T. kanzawai dan kurva tanggap fungsional tipe III dengan Th 7,68 menit dan a 0,22 telur/ menit.
\end{abstract}

Kata kunci: neraca hayati, preferensi, tanggap fungsional

\begin{abstract}
Tetranychus kanzawai Kishida is a species of mite that can cause agricultural crop losses of about $60-90 \%$. One way to control pests that are environmental friendly is to use the predatory beetle Stethorus punctillum Weise. This study aims to determine the demographic statistics, preferences, and functional response of S. punctillum on T. kanzawai. Observation of the S. punctillum biological using 100 eggs, observations were made of the number of individuals living until adult females produce offspring. Preferences of S. punctillum using 50 eggs and 50 nymphs and T. kanzawai adults, observations were made on the number of $T$. kanzawai preyed by instar larvae I, II, III, IV, and $S$. punctillum adults. Functional response is done by giving $S$. punctillum prey as many as 30, 40, 50, 60, 70, 80 eggs T. kanzawai, observations made on the remaining number of eggs. S. punctillum eggs last
\end{abstract}

*Penulis korespondensi: Nirma Septia Ramlan Anjas. Program Studi Entomologi, Departemen Proteksi Tanaman, Fakultas Pertanian, IPB Ubiversity, Jalan Kamper, Kampus IPB Dramaga, Bogor 16680, Tel: +6285299332462, Email: nirmaseptia@gmail.com 
for $7.01 \pm 0.72$ days. First instar larvae lasted for $4.84 \pm 0.51$ days, second instar $3.16 \pm 0.52$ days, third instar $3.00 \pm 0.27$ days, and IV instar $2.48 \pm 0.50$ days. Females lay eggs $64.47 \pm 2.37$ eggs. Gross reproduction rate (GRR) of S. punctillum 64.29 individuals/generation, net reproduction rate (Ro) of 17.18 individuals/female/generation, intrinsic accretion rate (r) of 0.27 individuals/female/ day, average the generation period (T) is 62.41 days, and the double time (DT) is 2.51 days. The data shows that $S$. punctillum has a preference for T. kanzawai egg stages and type III functional response curves with Th 7.68 minutes and a 0.22 eggs/minute.

Key words: functional response, life table, preference

\section{PENDAHULUAN}

Tetranychus kanzawai Kishida pertama kali ditemukan pada tanaman murbei di Jepang (Kishida 1927). Walter \& Proctor (1999) menyatakan bahwa sebelum perang dunia II, tungau ini merupakan hama sekunder yang menyebabkan kerusakan, namun tidak begitu berarti, tetapi penggunaan pestisida kimiawi secara intensif menyebabkan perubahan status pada spesies ini menjadi hama penting yang menyerang tanaman pertanian.

Spesies tungau ini bersifat kosmopolit dan dapat dijumpai hampir di seluruh belahan dunia (Kasap 2005). Tungau ini dikenal sebagai tungau laba-laba (spider mites) karena menghasilkan benang mirip jaring laba-laba pada tanaman inangnya, benang akan lebih banyak terbentuk pada populasi tungau tinggi. Pada umumnya tungau ini mudah dijumpai di lapangan, namun juga menjadi hama pada pertanaman dalam rumah kaca. Jika jumlah generasinya tinggi dalam satu musim tanam akan menyebabkan kerusakan yang besar (Kasap 2005).

Serangan tungau laba-laba sangat merusak karena baik nimfa maupun imagonya mengisap cairan dari daun, cabang muda, dan buah dari tanaman inangnya. Tungau mengeluarkan toksin pada waktu makan sehingga mengganggu proses metabolisme tanaman yang berakibat pada pengurangan serat, biji, dan buah serta menyebabkan daun menjadi kuning, kering, dan akhirnya daun gugur (Kasap 2005). Pada serangan yang berat dapat menyebabkan kematian tanaman. Tungau T. kanzawai merupakan salah satu hama penting yang menyerang tanaman ubi kayu dan dapat menyebabkan kerugian. Serangan tungau meningkat pada musim kemarau menyebabkan rontoknya daun dan tanaman ubi kayu, seperti mengeras dan tumbuhnya tunas-tunas baru pada setiap ketiak daun (Kasap 2005). Penurunan hasil akibat serangan hama ini dapat mencapai
20-53\%, bahkan hingga 95\% pada serangan berat (Kusumastuti 2007). Hasil penelitian lain menunjukkan bahwa penanaman ubi kayu di Lampung pada bulan Februari hingga Juni 2010 mengalami serangan hama tungau merah dengan intensitas tinggi sehingga menyebabkan semua daun luruh, sedangkan di Kebun Percobaan (KP) Muneng, Probolinggo, Jawa Timur ubi kayu yang ditanam pada musim kering mengalami serangan tungau merah dengan intensitas 54\%, menyebabkan kehilangan hasil 25-54\% (Indiati 2011). Hasil penelitian lain di rumah kaca menunjukkan bahwa serangan tungau merah dengan intensitas tinggi dapat menyebabkan kehilangan hasil hingga 95\% (Indiati 1999). Populasinya yang semakin meningkat menjadikan tungau merah ini sebagai hama penting pada tanaman pertanian sehingga perlu dilakukan pengendalian.

Saat ini cara yang banyak dilakukan untuk mengendalikan hama tersebut adalah penyemprotan dengan akarisida yang dapat menimbulkan masalah resistensi hama, peningkatan populasi hama, pencemaran lingkungan, dan residu pada produk pertanian. Oleh karena itu, untuk mengatasi permasalahan ini diperlukan cara pengendalian lain yang lebih aman dengan menggunakan agens hayati, seperti predator (Santoso 2012). Salah satu predator untuk mengendalikan tungau ini adalah kumbang Coleoptera: Coccinellidae, yaitu Stethorus sp. yang merupakan predator khusus tungau (Huffaker et al. 1969). Kemampuan memangsa Stethorus sp. tergolong tinggi baik pada stadium larva maupun imagonya. Dalam satu hari, imago Stethorus sp. mampu memangsa sekitar 9 imago tungau per jam, atau sekitar 75100 tungau per hari, larva instar tiga dan empat Stethorus sp. dapat memangsa sekitar 8 imago tungau per jam (Hull \& Horsburgh 2007). Hal ini mengindikasikan bahwa kumbang ini memiliki potensi untuk dimanfaatkan sebagai agens pengendali hayati untuk T. kanzawai. Meskipun 
demikian, keberhasilan pemanfaatan kumbang koksi predator sebagai agens pengendali hayati ditentukan oleh berbagai faktor ekologi dan biologi. Kajian tentang proses pertumbuhan suatu organisme biasanya disajikan secara sistematik pada sebuah tabel yang disebut neraca kehidupan, yang memuat data sintasan dan keperidian individu-individu dalam suatu populasi.

Studi tersebut meliputi kuantifikasi pola siklus hidup serta pengamatan pola perubahan dari mortalitas pada setiap tahap kehidupan. Sementara itu, aspek demografi suatu populasi terdapat dalam neraca kehidupan (life table) (Mawan \& Herma 2011). Di sisi lain, hasil studi tentang biologi, neraca kehidupan, dan demografi akan memberikan informasi tentang hubungan antara agens hayati dan hama sebagai mangsanya yang digunakan sebagai dasar untuk aplikasi di lapangan. Di dalam neraca kehidupan terdapat deskripsi yang sistematis tentang mortalitas dan kelangsungan hidup suatu populasi. Informasi tersebut merupakan informasi dasar yang diperlukan dalam menelaah perubahan kepadatan dan laju pertambuhan atau penurunan suatu populasi (Price 1997). Perubahanperubahan ukuran populasi dikenal dengan dinamika populasi. Sebagian populasi berubah ukurannya, dalam hal ini jumlah individu yang terlibat di dalamnya, menurut kondisi lingkungan yang sesuai untuk menghasilkan lebih banyak atau lebih sedikit individu dibandingkan dengan jumlah individu yang mati dalam selang waktu tertentu. Kelahiran, kematian, dan pergerakan merupakan tiga bagian perubahan dalam dinamika populasi. Statistik demografi suatu hama dapat digunakan untuk menentukan faktor kritis populasi hama serta untuk memahami pengaruh faktor-faktor eksternal terhadap agens pengendali biologi (Legaspi 2004). Selain itu, pemahaman statistik demografi hama sangat penting untuk memprediksi perkembangan populasi hama dan pengembangan strategi pengendalian hama tersebut (Tsai \& Liu 2000).

Pada umumnya, pertumbuhan populasi suatu mahluk hidup merupakan proses yang berlangsung kontiniu karena turun naiknya populasi dapat dipengaruhi oleh peristiwa-peristiwa yang berkaitan dengan perkembangan inang, musuhmusuh alami, dan faktor fisik lingkungan yang berlangsung pada periode waktu tertentu
(Tarumingkeng 1994). Oleh karena itu, penelitian ini bertujuan untuk mempelajari statistik demografi, preferensi, serta tanggap fungsional kumbang predator Stethorus punctillum Weise.

\section{BAHAN DAN METODE}

\section{Persiapan tanaman inang dan pemeliharaan tungau T. kanzawai}

Penelitian dilaksanakan di Laboratorium Ekologi Serangga, Departemen Proteksi Tanaman, Fakultas Pertanian, IPB University yang berlangsung dari bulan Oktober 2018 sampai Agustus 2019.

Tanaman ubi kayu digunakan untuk pemeliharaan tungau T. kanzawai sebagai mangsa kumbang predator. Pada penelitian ini digunakan ubi kayu varietas Manggu yang banyak ditanam petani di sekitaran kampus IPB Dramaga. Bibit ubi kayu 4 sampai 5 batang dimasukkan ke dalam wadah plastik berdiameter $15 \mathrm{~cm}$ yang berisi air hingga muncul tunas pada batang bibit. Setelah itu, tanaman ubi kayu diinfestasi tungau T. kanzawai dan dibiarkan berkembang. Tungau kemudian dijadikan mangsa kumbang predator, baik untuk pemeliharaan maupun perlakuan.

\section{Identifikasi dan pemeliharaan kumbang predator $S$. punctillum}

Kumbang predator yang diperoleh dari lahan pertanian dibawa ke laboratorium untuk diidentifikasi spesiesnya menggunakan kunci identifikasi dari Bienkowski (2018) "Key for Identification of The Ladybirds (Coleoptera: Coccinellidae) of European Russia and The Russian Caucasus (Native and Alien Species)". Kumbang predator S. punctillum selanjutnya dibiakkan pada kondisi laboratorium, dengan menggunakan tungau T. kanzawai sebagai mangsanya.

\section{Persiapan arena percobaan}

Arena percobaan berupa cawan petri berdiameter $8 \mathrm{~cm}$ yang didalamnya ditempatkan busa plastik diameter $7 \mathrm{~cm}$ yang jenuh air dan di atas busa plastik kemudian diletakkan kapas. Busa dan kapas selalu dalam kondisi basah. Setelah itu, potongan daun ubi kayu yang berukuran $3 \mathrm{~cm} x$ $3 \mathrm{~cm}$ diletakkan di atas kapas. 


\section{Neraca hayati $S$. punctillum}

Pengamatan terhadap berbagai indikator neraca hayati $S$. punctillum dimulai dari fase telur sampai imago. Sebanyak 100 telur $S$. punctillum ditempatkan secara individual pada arena percobaan. Pengamatan dilakukan setiap hari dengan bantuan mikroskop binokuler untuk melihat lama pergantian stadia dan jumlah predator yang masih hidup. Pada stadia dewasa kumbang jantan dan betina dipasangkan. Setelah itu, pengamatan dilakukan dengan melihat parameter, seperti fekunditas, keperidian, lama hidup, masa praoviposisi, oviposisi, dan pascaoviposisi. Selama pengamatan berlangsung, kumbang predator diberi mangsa berbagai stadia tungau T. kanzawai dalam jumlah yang melimpah. Data hasil pengamatan neraca hayati $S$. punctillum kemudian disajikan dalam tabel neraca hayati yang terdiri atas $\mathrm{x}$ : kelas umur (stadia) (hari); ax: banyaknya individu yang hidup pada setiap umur pengamatan; 1x: proporsi individu yang hidup pada umur $\mathrm{x}\left(\mathrm{l}_{\mathrm{x}}=\mathrm{a}_{\mathrm{x}} / \mathrm{a}_{\mathrm{o}}\right) ; \mathrm{m}_{\mathrm{x}}$ : keperidian spesifik individu-individu pada kelas umur $\mathrm{x}$ atau jumlah anak betina per induk yang lahir pada kelas umur $\mathrm{x}$; lxmx$_{\mathrm{x}}$ : banyak anak yang dihasilkan pada kelas umur.

Berdasarkan tabel neraca hayati, 5 statistik demografi S. punctillum ditentukan menggunakan rumus (Birch 1948) sebagai berikut:

1. Laju reproduksi bersih (Ro), dihitung dengan rumus: $\mathrm{R}_{0}=\sum 1_{\mathrm{x}} \mathrm{m}_{\mathrm{x}}$

2. Laju reproduksi kotor (GRR), dihitung dengan rumus: $\mathrm{GRR}=\sum \mathrm{m}_{\mathrm{x}}$

3. Laju pertambahan intrinsik (r), dihitung dengan rumus: $\sum 1_{x} m_{x} e-r_{x}=1$, dengan $r_{a w a l}=\left(\ln R_{0}\right) / T$

4. Rataan masa generasi ( $\mathrm{T})$, dihitung dengan rumus: $\mathrm{T}=\sum \mathrm{xl}_{\mathrm{x}} \mathrm{m}_{\mathrm{x}} / \sum \mathrm{l}_{\mathrm{x}} \mathrm{m}_{\mathrm{x}}$

5. Waktu populasi berlipat ganda (DT), dihitung dengan rumus: $\mathrm{DT}=\ln (2) / \mathrm{r}$

\section{Preferensi S. punctillum terhadap stadia T. kanzawai}

Percobaan ini dilakukan untuk mengetahui preferensi mangsa dari kumbang predator $S$. punctillum terhadap stadia mangsa (telur, nimfa, dan imago) tungau hama T. kanzawai. Cawan petri dibagi menjadi 3 ruangan yang sama besar dan antar ruangan diberi pembatas. Daun ubi kayu yang telah diinokulasikan telur, nimfa, dan imago tungau T. kanzawai, masing-masing sebanyak 50 butir per 50 individu, dimasukkan pada setiap ruangan. Selanjutnya, sebanyak 1 individu larva instar 1, 2, 3, 4, dan imago S. punctillum dilepaskan tepat di tengah-tengah cawan petri tersebut (Legaspi et al. 2006). Larva dan imago $S$. punctillum ini sebelumnya telah dipuasakan selama 24 jam. Perlakuan ini diulang sebanyak 5 kali ulangan. Peubah yang diamati adalah jumlah telur, nimfa, dan imago tungau T. kanzawai yang tersisa pada masing-masing cawan petri.

\section{Tanggap fungsional kumbang predator S. punctillum}

Mangsa yang digunakan dalam percobaan ini adalah stadia telur T. kanzawai. Kepadatan telur yang digunakan adalah $30,40,50,60,70$, dan 80 butir telur. Masing-masing perlakuan diulang 5 kali. Satu imago predator yang sebelumnya telah dipuasakan selama 24 jam, dimasukkan ke dalam arena percobaan yang berisi telur tungau dan dibiarkan selama 24 jam. Setelah itu, jumlah telur yang tersisa pada arena percobaan dihitung. Percobaan dilakukan dengan rancangan acak lengkap. Tipe kurva tanggap fungsional ditentukan menggunakan analisis regresi logistik, antara proporsi mangsa yang diserang $\left(\mathrm{N}_{\mathrm{e}} / \mathrm{N}_{\mathrm{o}}\right)$ sebagai peubah terpengaruh dan kepadatan awal telur $T$. kanzawai sebagai peubah yang mempengaruhi. Data tanggap fungsional diuji sesuai pada fungsi polinom yang menggambarkan hubungan $\mathrm{Ne}_{\mathrm{e}} / \mathrm{N}_{\mathrm{o}}$ sebagai berikut:

$$
\frac{N_{\varepsilon}}{N_{o}}=\frac{\exp \left(P_{0}+P_{1} N_{0}+P_{2} N_{0}^{2}+P_{8} N_{0}^{8}\right)}{1+\exp \left(P_{0}+P_{1} N_{0}+P_{2} N_{0}^{2}+P_{8} N_{0}^{8}\right)}, \text { dengan }
$$

$\mathrm{P}_{0}$ : intercept; $\mathrm{P}_{1}$ : koefisien linear; $\mathrm{P}_{2}$ : koefisien kuadratik; dan $\mathrm{P}_{3}$ : koefisien kubik. Pendugaan parameter $\left(\mathrm{P}_{0}, \mathrm{P}_{1}, \mathrm{P}_{2}, \mathrm{P}_{3}\right)$ dilakukan menggunakan bantuan perangkat lunak Minitab. Tanggap fungsional tipe II akan digambarkan dengan nilai $\mathrm{P}_{1}$ yang lebih kecil dari 0 atau negatif $\left(\mathrm{P}_{1}<0\right)$. Tanggap fungsional tipe III akan digambarkan dengan nilai $\mathrm{P}_{1}$ yang positif $\left(\mathrm{P}_{1}>0\right)$, namun $\mathrm{P}_{2}$ bernilai negatif $\left(\mathrm{P}_{2}<0\right)$. Pada tanggap fungsional tipe II dan III terdapat waktu penanganan mangsa (Th) dan laju pencarian mangsa (a). Pendugaan Th dan a didapatkan dari persamaan cakram Holling (1959) untuk tanggap fungsional tipe II dan persamaan Hassell (1977) untuk tanggap fungsional tipe III. 


\section{Analisis data}

Analisis terhadap data neraca hayati dilakukan dengan perangkat lunak Microsoft Excel 2010. Analisis terhadap data preferensi mangsa dan pengaruh kepadatan awal mangsa terhadap jumlah yang dimangsa oleh predator dilakukan dengan analisis ragam dan dilanjutkan dengan Uji Tukey pada taraf nyata $5 \%$. Analisis terhadap penentuan tipe fungsi tanggap fungsional dan pendugaan parameternya dilakukan dengan regresi logistik dan regresi nonliniear dengan bantuan perangkat lunak Minitab 18.

\section{HASIL}

\section{Neraca hayati dan statistik demografi S. punctillum}

Hasil penelitian menunjukkan bahwa $S$. punctillum termasuk tipe III yang memperlihatkan kematian yang lebih besar pada populasi berumur muda atau stadium awal (Gambar 1). Penelitian ini dilakukan pada kondisi sumber makanan tidak terbatas dan lingkungan bebas musuh alami sehingga kematian yang terjadi dapat disebabkan oleh genetik dan kondisi lingkungan pada saat pengujian. Berdasarkan pola kurva kesintasan mengindikasikan bahwa stadium awal pradewasa rentan terhadap gangguan fisik pada saat pemeliharaan dan kualitas makanan.

Kurva reproduksi harian $\left(m_{x}\right)$ menunjukkan periode peletakkan telur dimulai sejak betina berumur 41 hari dengan rataan 1,5 butir telur. Jumlah telur yang diletakkan kemudian meningkat drastis dengan kisaran rataan 2,5 butir yang terjadi pada imago berumur 52 hari. Peletakan telur terhenti pada saat imago betina berumur 99 hari.
Telur S. punctillum berlangsung selama 7,01 \pm 0,72 hari, larva instar-1 4,84 $\pm 0,51$ hari, instar-2 $3,16 \pm 0,52$ hari, instar-3 3,00 $\pm 0,27$ hari, dan instar-4 2,48 $\pm 0,50$ hari. Kemampuan betina menghasilkan telur sebanyak $64,47 \pm 2,37$ butir. Masa hidup imago betina lebih lama 90,64 $\pm 1,07$ hari, sedangkan imago jantan $47,14 \pm 2,47$ hari (Tabel 1).

Berbagai parameter neraca hayati $S$. punctillum yang meliputi rataan masa generasi $(\mathrm{T})$, laju reproduksi bersih (Ro), laju reproduksi kotor (GRR), laju pertambahan intrinsik (r), dan waktu ganda (DT), disajikan pada Tabel 2. Laju reproduksi bersih (Ro) kumbang predator $S$. punctillum sebesar 17,18 butir telur per generasi dan laju reproduksi kotor (GRR) adalah 64,29 individu per generasi. Nilai ini menunjukkan bahwa pada keadaan faktor makanan tidak sebagai pembatas, populasi $S$. punctillum dapat berkembang sebanyak 17,18 kali dalam satu generasi selama 62,41 hari. Tingginya laju pertumbuhan bersih (Ro) akan memperpendek waktu generasi (T). Pada penelitian ini, masa generasi (T) S. punctillum, yakni 62,41 hari dan nilai laju pertambahan intrinsik (r) adalah 0,27 individu/betina/hari. Waktu yang dibutuhkan populasi $S$. punctillum untuk berlipat ganda (DT) adalah 2,51 hari (Tabel 2). Nilai DT yang rendah dapat meningkatkan laju reproduksi kotor (GRR) dan laju reproduksi bersih ( $\left.R_{0}\right)$ dalam waktu tertentu.

\section{Preferensi kumbang predator $S$. punctillum}

Hasil uji preferensi pada stadia mangsa yang berbeda menunjukkan bahwa $S$. punctillum larva instar-1, instar 2, instar 3, instar 4, dan imago lebih menyukai stadia telur dari T. kanzawai. Hal

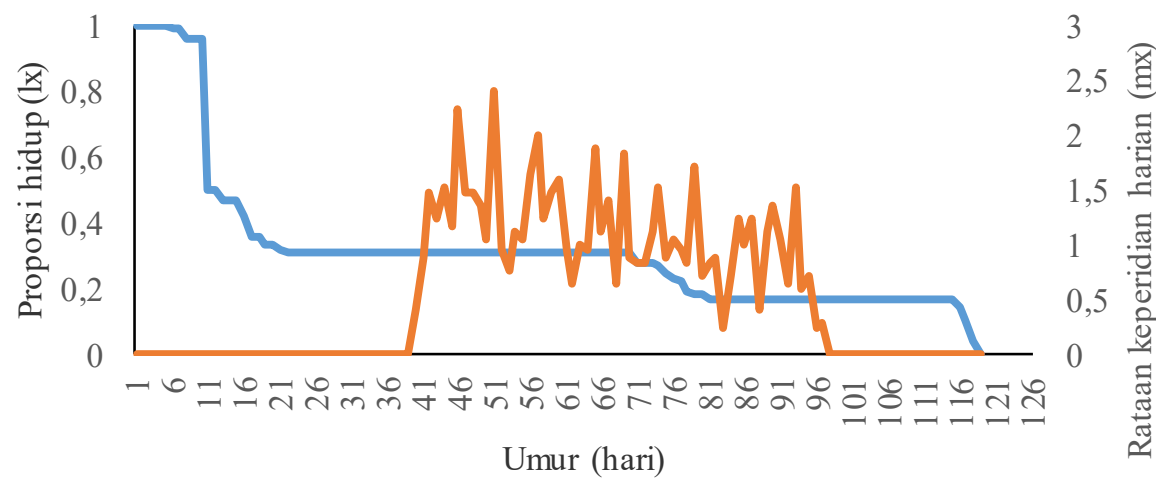

Gambar 1. Kurva sintasan dan reproduksi harian Stethorus punctillum. — : proporsi individu hidup (1x); : rata-rata keperidian $\left(m_{x}\right)$. 
ini menunjukkan bahwa $S$. punctillum memiliki ketertarikan yang cukup tinggi dalam memangsa stadia telur T. kanzawai (Tabel 3).

\section{Tanggap fungsional predator S. punctillum}

Hasil analisis regresi logistik predasi $S$. punctillum pada mangsa telur T. kanzawai diperlihatkan pada Tabel 4. Hubungan kepadatan mangsa dan tingkat predasi memperlihatkan tanggap fungsional tipe III. Hal tersebut ditunjukkan oleh koefisien $\mathrm{P}_{1}$ bernilai positif dan $\mathrm{P}_{2}$ bernilai negatif. Waktu penanganan mangsa (Th) dan laju pencarian mangsa (a) merupakan salah satu karakter penting dalam interaksi mangsapredator. Waktu penanganan ini meliputi mengenal, memburu, dan menangani mangsa. Laju pencarian mangsa menunjukkan proporsi dari total area yang dijelajahi predator per unit waktu jelajah, dan laju pencarian predator S. punctillum terhadap telur T. kanzawai (a) adalah 0,22 menit. Nilai masa penanganan mangsa (Th) dari S. punctillum terhadap telur T. kanzawai adalah 7,68 menit.

Tingkat pemangsaan terendah, yaitu 28 butir telur terjadi pada saat kepadatan mangsa hanya 30 butir telur mangsa. Tingkat pemangsaan tertinggi, yaitu 79,6 butir pada saat kepadatan mangsa

Tabel 1. Indikator Biologi Stethorus punctillum pada Tetranychus kanzawai

\begin{tabular}{lcc}
\hline Indikator biologi & $\mathrm{n}$ & Rata-rata \pm SB \\
\hline Stadia perkembangan & & Lama (hari) \\
Telur & 100 & $7,01 \pm 0,72$ \\
Larva instar 1 & 50 & $4,84 \pm 0,51$ \\
Larva instar 2 & 38 & $3,16 \pm 0,52$ \\
Larva instar 3 & 34 & $3,00 \pm 0,27$ \\
Larva instar 4 & 33 & $2,48 \pm 0,50$ \\
Pupa & 31 & $5,32 \pm 0,59$ \\
Imago jantan & 14 & $47,14 \pm 2,47$ \\
Imago betina & 17 & $90,64 \pm 1,07$ \\
Praoviposisi & 17 & $15,23 \pm 1,52$ \\
Oviposisi & 17 & $52,82 \pm 1,84$ \\
Pascaoviposisi & 17 & $22,58 \pm 2,03$ \\
Keperidian (individu) & 17 & $64,47 \pm 2,37$ \\
\hline
\end{tabular}

Tabel 2. Statistik demografi kumbang predator Stethorus punctillum

\begin{tabular}{lrc}
\hline Statistik demografi & Nilai & Satuan \\
\hline GRR & 64,29 & individu/generasi \\
Ro & 17,18 & individu/betina/generasi \\
r & 0,27 & individu/betina/hari \\
DT & 2,51 & hari \\
T & 62,41 & hari \\
\hline
\end{tabular}

GRR: laju reproduksi kotor; Ro: laju reproduksi bersih; r: laju pertambahan instrinsik; T: rataan masa generasi; DT: waktu populasi berlipat ganda

Tabel 3. Rataan jumlah mangsa yang dimangsa predator Stethorus punctillum pada telur, nimfa, dan imago Tetranychus kanzawai

\begin{tabular}{lccccc}
\hline \multirow{2}{*}{$\begin{array}{l}\text { Stadia } T . \\
\text { kanzawai }\end{array}$} & \multicolumn{5}{c}{ Jumlah individu yang dimangsa pada setiap stadia predator (Rerata $\pm \mathrm{SB}$ )* } \\
\cline { 2 - 6 } & Instar 1 & Instar 2 & Instar 3 & Instar 4 & Imago \\
\hline Telur & $54,01 \pm 3,31 \mathrm{a}$ & $49,50 \pm 2,25 \mathrm{a}$ & $48,04 \pm 2,13 \mathrm{a}$ & $46,10 \pm 1,37 \mathrm{a}$ & $44,23 \pm 0,66 \mathrm{a}$ \\
Nimfa & $18,85 \pm 3,92 \mathrm{c}$ & $31,15 \pm 3,03 \mathrm{~b}$ & $29,73 \pm 1,62 \mathrm{~b}$ & $30,94 \pm 1.69 \mathrm{~b}$ & $30,90 \pm 0,63 \mathrm{c}$ \\
Imago & $27,14 \pm 4,22 \mathrm{~b}$ & $19,35 \pm 2,89 \mathrm{c}$ & $22,23 \pm 1,34 \mathrm{c}$ & $22,96 \pm 2,71 \mathrm{c}$ & $24,87 \pm 0,24 \mathrm{~b}$ \\
\hline
\end{tabular}

*Nilai rataan yang diikuti huruf yang berbeda pada setiap kolom menunjukkan perbedaan nyata berdasarkan uji Tukey $(\alpha=$ $0,05)$. 
berjumlah 80 butir telur. Rataan jumlah telur yang dimangsa kumbang predator pada kepadatan mangsa yang berbeda dapat dilihat pada (Tabel 5). Tingkat pemangsaan predator akan meningkat dengan peningkatan jumlah mangsa.

Kurva tanggap fungsional kumbang predator S. punctillum yang diberi mangsa telur tungau hama T. kanzawai menunjukkan bahwa tingkat pemangsaan predator akan meningkat seiring dengan penambahan kepadatan mangsa (Gambar 2).

\section{PEMBAHASAN}

Pola kurva kesintasan S. punctillum memperlihatkan bahwa stadium awal pradewasa rentan terhadap gangguan fisik pada saat pemeliharaan dan kualitas makanan. Laju reproduksi kotor merupakan nilai rata-rata jumlah individu betina yang dihasilkan oleh induk betina dalam satu generasi. Menurut Price (1997), laju reproduksi bersih adalah jumlah keturunan betina yang mampu dihasilkan oleh rata-rata individu induk tiap generasi. Menurut Kurniawan (2007) nilai Ro dan GRR yang tinggi memperlihatkan tingkat kesesuaian hidup serangga predator terhadap mangsa. Dengan mengetahui nilai Ro dan $\mathrm{T}$ maka dapat ditentukan laju pertambahan intrinsik (r) generasi tersebut (Andrewartha 1982). Laju pertambahan instrinsik (r) merupakan pertambahan populasi pada lingkungan konstan dan sumber daya yang tidak terbatas (Birch 1948). Semakin tinggi persentase telur yang diletakkan pada kelompok umur muda maka akan semakin besar nilai laju pertambahan intrinsik (r) organisme tersebut (Birch 1948).

Tabel 4. Hasil analisis regresi logistik proporsi mangsa Tetranychus kanzawai yang dimangsa imago Stethorus punctillum

\begin{tabular}{lccc}
\hline Parameter & Nilai penduga & Standart error & $P$-value \\
\hline Intercept & $-8,71$ & 6,54 & 0,183 \\
Linear & 0,76 & 0,40 & 0,061 \\
Kuadratik & $-0,01$ & 0,00 & 0,045 \\
Kubik & 0,00 & 0,00 & 0,030 \\
\hline
\end{tabular}

Tabel 5. Rataan jumlah mangsa yang dimangsa imago Stethorus punctillum

\begin{tabular}{lc}
\hline Kepadatan mangsa (butir) & Rataan jumlah mangsa yang dimangsa* \\
\hline 30 & $28,0 \mathrm{a}$ \\
40 & $38,6 \mathrm{~b}$ \\
50 & $47,4 \mathrm{c}$ \\
60 & $56,8 \mathrm{~d}$ \\
70 & $68,2 \mathrm{e}$ \\
80 & $79,6 \mathrm{f}$ \\
\hline Rataan & 53,1 \\
\hline . nilai rataan yang diikuti huruf yang berbeda pada setiap kolom menunjukkan perbedaan nyata berdasarkan uji Tukey $(\alpha=$
\end{tabular}

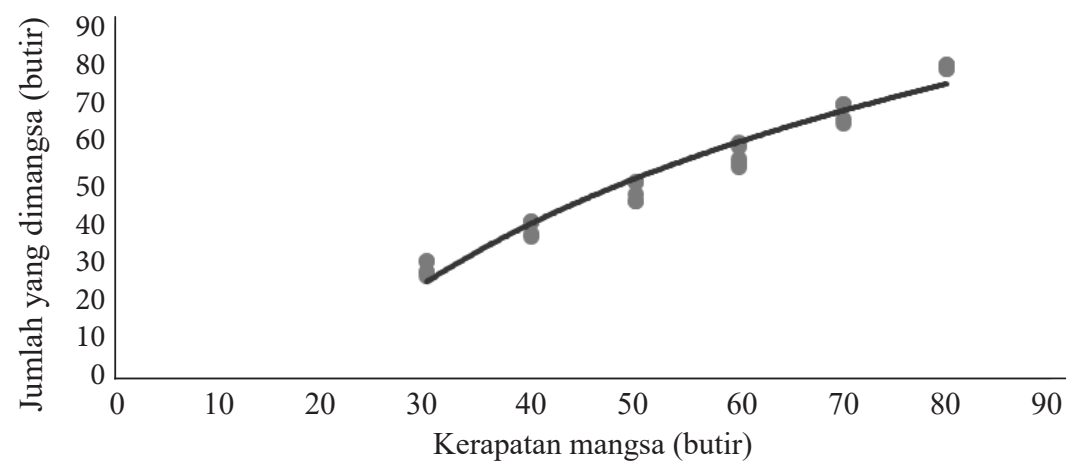

Gambar 2. Kurva tanggap fungsional Stethorus punctillum. 
Siklus hidup kumbang S. punctillum terdiri atas telur, larva, pupa, dan imago. Telur relatif kecil berukuran sekitar $\pm 0,37 \mathrm{~mm}$, berbentuk oval dan berwarna putih pucat keoranyean. Telur yang telah menetas ditandai dengan perubahan warna menjadi putih transparan dan terdapat eksuvia pada daun. Setelah 7 hari, larva keluar dari telur dan mulai memakan semua stadia tungau.

Larva yang baru menetas tubuhnya keabuabuan sampai kuning dan mempunyai banyak rambut (Rahardita 2008). Larva mempunyai 13 segmen termasuk kepalanya. Larva melalui empat stadia dan menjadi pupa dalam 12 hari. Perkembangan larva instar pertama dan instar berikutnya ditandai dengan adanya eksuvia sebagai tanda larva sudah mengalami pergantian kulit dan semakin banyaknya rambut-rambut serta bertambahnya ukuran tubuh larva. Panjang tubuh larva berkisar 0,7-1 $\mathrm{mm}$ dengan rambut-rambut disepanjang tubuhnya.

Pupa S. punctillum berwarna hitam, kecil, dan pada seluruh tubuhnya terdapat rambut berwarna kuning dan bantalan sayap yang menonjol. Pada akhir pupasi warnanya menjadi oranye kemerahan. Pupasi berlangsung selama 5 hari.

Imago S. punctillum berbentruk oval, cembung, hitam mengkilap, dan terdapat rambut halus berwarna kekuningan sampai putih pada tubuhnya. Panjang tubuh 1,00-1,5 mm dan lebar $1,2 \mathrm{~mm}$ relatif lebih kecil dari kumbang Coccinellidae lainnya. Tungkai berwarna kekuningan dan sama halnya dengan kumbang koksi pada umumnya sayap depannya mengeras dan tebal yang ditutupi dengan banyak rambut-rambut. Beberapa jam setelah menjadi imago, akan mulai mencari mangsa dan kawin. Imago memerlukan 25 hari untuk menghasilkan telur (Rahardita 2008). Imago betina menghasilkan 1-13 telur yang diletakkan satu per satu. Telur biasanya ditempatkan pada daun di dekat pembuluh utama, letaknya 95\% di bawah permukaan daun dan 5\% di atas permukaan daun. Penelitian Taghizadeh et et al. (2008) dan Perumalsamy et al. (2010) telah menunjukkan bahwa suhu dan kelembaban relatif sangat mempengaruhi fekunditas dan ketahanan hidup kumbang Stethorus. Predator jantan akan pindah dan mencari betina ketika waktu kawin datang, namun tidak semua betina bersedia untuk kawin. Betina akan memperluas sayap depannya, lalu bergerak melingkar agar energinya habis lalu mati untuk menghindari proses kawin tersebut. Kawin biasanya terjadi pada permukaan daun. Satu periode kawin dapat berlangsung selama lebih dari satu jam, dimana jantan akan memposisikan diri di atas tubuh betina dan memperpanjang aedeagus untuk mencapai betina, di sisi lain bagian anterior dari jantan akan pindah dari kiri ke kanan selama proses kawin.

Imago kumbang $S$. punctillum sangat aktif memangsa ketika jumlah mangsanya melimpah, tetapi ketika populasi mangsanya rendah kumbang S. punctillum akan berpindah. Imago S. punctillum dapat memangsa 75-100 tungau tiap hari dan larvanya dapat memangsa sampai 75 tungau tiap hari sehingga kumbang predator $S$. punctillum dapat menekan populasi tungau dengan cepat. Kepadatan populasi tungau yang tinggi menyebabkan perkembangan kumbang predator ini semakin cepat (Rahardita 2008).

Jenis, stadia, dan ukuran tubuh mangsa yang bervariasi memiliki pengaruh terhadap preferensi predator (Li 2002). Penyebab kurang sukanya predator terhadap stadia nimfa dan imago mangsanya tersebut mungkin karena bentuk dan ukuran tubuh mangsa, semakin besar bentuk dan ukuran mangsa maka semakin sulit predator untuk memangsanya. Stethorus memangsa dari bagian depan atau samping dari tubuh mangsanya kemudian dikunyah dan Stethorus mengisap semua cairan tubuh mangsa dengan menyisipkan mandibula ke daerah tubuh mangsanya. Kumbang predator $S$. punctillum larva instar 1 sampai imagonya mempunyai preferensi tertinggi (lebih menyukai) stadia mangsa berupa telur dibandingkan dengan stadia nimfa dan imagonya. Menurut (De Bach 1976) predator akan menyeleksi kecocokan mangsanya dan seleksi tersebut berlangsung secara alamiah. Beberapa komponen yang berpengaruh pada preferensi predator terhadap mangsa adalah ketertarikan dan kesesuaian terhadap mangsa, pengenalan terhadap mangsa, keputusan untuk menyerang atau tidak, menangkap serta mengkonsumsi mangsa (Cisneros \& Rosenheim 1998).

Tanggap fungsional tipe III merupakan satusatunya tipe tanggap fungsional yang memiliki kontribusi nyata dalam regulasi populasi hama (Hassell 1978). Fernandez \& Corley (2003) 
menambahkan bahwa predator atau parasitoid yang memiliki tanggap fungsional tipe III berpotensi sebagai agens biokontrol yang efisien. Laju pemangsaan diduga berkaitan dengan waktu penanganan mangsa (mengenal dan memburu), preferensi predator akan menentukan laju pencarian mangsa (Tarumingkeng 1992). Ketika kepadatan populasi mangsa rendah maka predator membutuhkan waktu yang relatif panjang untuk menghasbiskan satu mangsa, namun pada kepadatan populasi mangsa yang tinggi, predator membutuhkan waktu yang relatif singkat untuk memangsa satu individu.

\section{KESIMPULAN}

Masa perkembangan pradewasa kumbang predator S. punctillum pada tungau T. kanzawai menunjukkan bahwa telur $S$. punctillum berlangsung selama 7,01 $\pm 0,72$ hari, larva instar I $4,84 \pm 0,51$ hari, instar II $3,16 \pm 0,52$ hari, instar III 3,00 $\pm 0,27$ hari, dan instar IV 2,48 \pm 0,50 hari. Imago betina mampu meletakkan telur sebanyak $64,47 \pm 2,37$. Laju reproduksi kotor (GRR) S. punctillum 64,29 individu/generasi, (laju reproduksi bersih (Ro) 7,18 individu/betina/ generasi, laju pertambahan intristik (r) 0,27 individu/betina/hari, rata-rata masa generasi $(\mathrm{T})$ 62,41 hari, dan waktu ganda (DT) 2,51 hari. $S$. punctillum lebih menyukai telur dibandingkan dengan stadia lain dari T. kanzawai. Predator ini memiliki tanggap fungsional type III dengan Th 7,68 menit dan a 0,22 telur/menit.

\section{DAFTAR PUSTAKA}

Andrewartha HG. 1982. Selections From the Distribution and Abundance of Animals. Chicago: University of Chicago.

Bienkowski AO. 2018. Key for identification of the ladybirds (Coleoptera: Coccinellidae) of European Russia and the Russian Caucasus (native and alien species). Zootaxa 4472:233. doi: https://doi.org/10.11646/zootaxa.4472.2.2.

Birch LC 1948. The intrinsic rate of natural increase of an insect population. Journal of Animal Ecology 23:513-524.

Cisneros JJ, Rosenheim JA. 1998. Changes in the foraging behavior, within plant vertical distribution, and microhabitat selection of a generalist insect predator: an age analysis. Environmental Entomology 27:949-957. doi: https://doi.org/10.1093/ee/27.4.949.

De Bach P. 1976. Biological Control of Insect Pests and Weeds. London: Chapman and Hall.

Fernandez-Arhex V, Corley JC. 2003. The functional response of parasitoids and its implications for biological control. Biocontrol Science and Technology 13:403-413. doi: https://doi.org/10.1 080/0958315031000104523.

Hassell MP, Lawton JH, Beddington JR. 1977. Sigmoid fungtional responses by invertabrate predators and parasitoid. Journal of Animal Ecology 46:249-262. doi: https://doi. org $/ 10.2307 / 3959$.

Hassell MP. 1978. Monographs in Population Biology: the dynamics of arthropod predator prey systems. New Jersey: Princeton University Press.

Hull LA, Horsburgh L. 2007. Stethorus punctum. Tersedia pada: http://www.ento.vt.edu/Fruitfiles/ Stethorus.html. [diakses 27 September 2019].

Hull LA. 1995. Know your friends: Stethorus punctum, Midwest Biological Control News. Tersedia pada: http://www.entomology.wisc. edu/mbcn/kyf212.html. [diakses 27 September 2019].

Huffaker CBM, Van de Vrie, JA McMurty. 1969. The ecology of tetranychid mites and their natural control. Annual Review of Entomology 14:125174. doi: https://doi.org/10.1146/annurev. en.14.010169.001013.

Holling CS. 1959. Some characteristics of simple types of predation and parasitism. The Canadian Entomologist 91:385-398. doi: https://doi. org/10.4039/Ent91385-7.

Indiati SW. 1999. Status tungau merah pada tanaman ubi kayu. Di dalam: AA Rahmianna (Ed.), Pemberdayaan Tepung Ubijalar Sebagai Substitusi Terigu, dan Potensi Kacang-kacangan untuk Pengayaan Kualitas Pangan. hlm. 122126. Malang: Balitkabi.

Indiati SW. 2011. Serangan hama tungau merah, Tetranychus urticae pada beberapa varietas ubi kayu. Di dalam: Makalah Seminar di BPTP Lampung (Bandar lampung, 5 April 2011). Lampung: BPTP.

Kasap I. 2005. Life history traits of the predaceous mite Kampimodromus aberrans Oudemans (Acarina: Phytoseiidae) on four different types of food. Biological Control 35:40-45. doi: https:// doi.org/10.1016/j.biocontrol.2005.05.014. 
Kishida K. 1927. Illustrated Encyclopedia of the Fauna of Japan. Tokyo: Hokuryukan Company Limited.

Kurniawan HA. 2007. Neraca Kehidupan Kutu Kebul, Bemisia tabaci Gennadius (Hemiptera: Aleyrodidae) Biotipe-B dan Non-B pada Tanaman Mentimun (Curcumas sativus L.) dan Cabai (Capsicum annuum L.). Tesis. Bogor: Institut Pertanian Bogor.

Kusumastuti CT. 2007. Singkong Sebagai Salah Satu Sumber Bahan Bakar Nabati (BBN). Skripsi. Yogyakarta: Universitas Gajah Mada.

Li Y. 2002. Biomolecular screening with encoded porous-silicon photonic crystals. Nature Mater 1:39-41. doi: https://doi.org/10.1038/ nmat702.

Legaspi JC. 2004. Prey preference by Delphastus catalinae (Coleoptera: Coccinellidae) on Bemisia argentifolii (Homoptera:Aleyrodidae): effects of plant species and prey stages. Florida Entomologist 89:218-222. doi: https://doi. org/10.1653/0015-4040(2006)89[218:PPBDCC ]2.0.CO;2.

Legaspi JC, Simmons AM, Legaspi Jr BC. 2006. Prey preference by Delphastus catalinae (Coleoptera: Coccinellidae) on Bemisia argentifolii (Homoptera: Aleyrodidae): effects of plant species and prey stages. Bioone Online Journals 89:218-222. doi: https://doi.org/10.1653/00154040(2006)89[218:PPBDCC]2.0.CO;2.

Mawan AH Amalia. 2011. Statistik demografi Riptortus linearis F. (Hemiptera: Alydidae) pada kacang panjang (Vigna sinensis L.). Jurnal Entomologi Indonesia 8:8-16. doi: https://doi. org/10.5994/jei.8.1.8.

Perumalsamy KR, Selvasundaram R, Roobakkumar A, Rahman VJ, Muraleedharan N. 2010. Life table and predatory efficiency of Stethorus gilvifrons (Coleoptera: Coccinell-idae), an important predator of the red spider mite, Oligonychus coffeae (Acari: Tetranychidae), infesting tea. Experimental and Applied Acarology. 50:141150. doi: https://doi.org/10.1007/s10493-0099290-y.
Price PW. 1997. Insect Ecology. Edisi ke-3. New York: John Wiley and Sons Inc.

Rahardita NP. 2008. Daya Mangsa Stethorus sp. (Coleoptera: Coccinellidae) dan Coccinellid, Predator Tungau Tetranychus sp. (Acari: Tetranychidae). Skripsi. Malang: Universitas Brawijaya.

Santoso S. 2012. Pengembangan dan Pemanfaatan Tungau Predator Neoseiulus longispinosus (Acari: Phytoseiidae) sebagai Agens Pengendalian Hayati Tungau Hama. Bogor: LPPM Institut Pertanian Bogor.

Tarumingkeng RC. 1992. Dinamika Pertumbuhan Populasi Serangga. Bogor: IPB Press.

Tarumingkeng RC. 1994. Dinamika Populasi: Kajian Ekologi Kuantitatif. Jakarta: Pustaka Sinar Harapan.

Taghizadeh RY, Fathipour, K Kamali. 2008. Influence of temperature on lifetable parameters of Stethorus gilvifrons (Mulsant) (Coleoptera: Coccinellidae) fed on Tetranychus urticae Koch. Journal of Applied Entomology 132:638645. doi: https://doi.org/10.1111/j.14390418.2008.01276.x.

Tsai JH, Liu YH. 2000. Biology of Diaphorina citri (Homoptera: Psyllidae) on four host plants. Journal of Economic Entomology 93:17211725. doi: https://doi.org/10.1603/0022-049393.6.1721.

Walter D, Proctor H. 1999. Mites: Ekology, Evolution and Behavior. New York: CABI. 